\title{
Paternal concentrations of dioxin and sex ratio of offspring
}

\author{
Paolo Mocarelli, Pier Mario Gerthoux, Enrica Ferrari, Donald G Patterson Jr, Stephanie M Kieszak, Paolo Brambilla, \\ Nicoletta Vincoli, Stefano Signorini, Pierluigi Tramacere, Vittorio Carreri, Eric J Sampson, Wayman E Turner, \\ Larry L Needham
}

\begin{abstract}
Summary
Background 2,3,7,8-Tetrachlorodibenzo-p-dioxin (TCDD or dioxin), is commonly considered the most toxic man-made substance. We have previously shown that high serum concentrations of TCDD in parents from Seveso, Italy, were linked to their having a relative increase in the number of female births after the parents exposure to a release of dioxin in 1976. We have continued the study to determine whether the parents' sex and/or age at exposure affected the sex ratio of their children.
\end{abstract}

Methods We measured the TCDD concentrations in serum samples from potentially exposed parents collected in 1976 and 1977, and investigated the sex ratio of their offspring.

Findings Serum samples were collected from 239 men and 296 women. 346 girls and 328 boys were born to potentially exposed parents between 1977 and 1996, showing an increased probability of female births (lower sex ratio) with increasing TCDD concentrations in the serum samples from the fathers $(p=0.008)$. This effect starts at concentrations less than $20 \mathrm{ng}$ per $\mathrm{kg}$ bodyweight. Fathers exposed when they were younger than 19 years of age sired significantly more girls than boys (sex ratio $0.38[95 \% \mathrm{Cl}$ $0.30-0 \cdot 47])$.

Interpretation Exposure of men to TCDD is linked to a lowered male/female sex ratio in their offspring, which may persist for years after exposure. The median concentration of dioxin in fathers in this study is similar to doses that induce epididymal impairments in rats and is about 20 times the estimated average concentration of TCDD currently found in human beings in industrialised countries. These observations could have important public-health implications.

Lancet 2000; 355: 1858-63

See Commentary page ???

\section{Introduction}

Polychlorinated dibenzo- $p$-dioxins (PCDDs), polychlorinated biphenyls (PCBs), and polychlorinated dibenzofurans (PCDFs) are products and byproducts of industrial or combustion processes. These compounds have been identified in almost all animal species, including humans. Some of these chemicals can disrupt multiple endocrine pathways and induce a wide range of toxic responses depending on target organs, sex, age, and species. ${ }^{1,2}$

We have previously described ${ }^{3}$ a substantially lower male/female sex ratio at birth in the offspring of people exposed to high concentrations of 2,3,7,8tetrachlorodibenzo-p-dioxin (TCDD or dioxin). This residential exposure occurred after an explosion at a plant that manufactured the herbicide 2,4,5trichlorophenol (TCP), in Seveso, Italy, on July 10, 1976. This explosion probably released more than $30 \mathrm{~kg}$ of dioxin into the environment. ${ }^{4}$ However, the population of YuCheng in Taiwan, which was exposed to high concentrations of PCBs and PCDFs, did not show a significant deviation from the normal sex ratio. ${ }^{5}$ Some chemicals such as the fertility drug clomifene, the nematocide dibromochloropropane (DBCP), and selected anaesthetic gases have been linked to sex-ratio changes in other populations. ${ }^{6}$

Worldwide, the sex ratio at birth in human beings is fairly constant-106 men for every 100 women, or, as is sometimes reported, the male proportion of total births (106 male births divided by 206 total births) is 0.514 $(51 \cdot 4 \%) .{ }^{7}$ Researchers, however, have reported a decreased proportion of male births in the general population in Denmark, ${ }^{8}$ Netherlands, ${ }^{9}$ USA, ${ }^{10}$ Canada, ${ }^{11}$ in selected populations such as in sawmill-industry workers who were exposed to trichlorophenate contaminated with various dioxin congeners, ${ }^{12,13}$ and in individuals exposed to air pollution from incinerators. ${ }^{14} \mathrm{~A}$ lower sex ratio has been seen in Italian metropolitan areas compared with the rest of the country. ${ }^{15}$ The main hypothesis is that environmental chemical pollution is responsible for this phenomenon ${ }^{6}$ even if many of the components or the concentrations of the known components of the air pollution have not been fully identified. ${ }^{16}$ The possible origin (paternal, maternal, or both) of the slight increase in female births is not clear. James $^{7}$ strongly supports that parental hormone concentrations at the time of conception are a main regulating factor of sex ratio at birth, but no definitive proof is available.

We measured the TCDD concentrations in serum samples taken in the years 1976 and 1977 from parents potentially exposed to the chemical, and we compared these concentrations to the sex of their offspring born between 1977 and 1996. We also aimed to determine whether the parents' sex and/or age at exposure affected the sex ratio. 
130 men with measured TCDD concentrations, married to females living outside zones $\mathrm{A}, \mathrm{B}$ and $\mathrm{R}$
154 females with measured TCDD concentrations married to males living outside zones $\mathrm{A}, \mathrm{B}$, and $\mathrm{R}$ in 1976

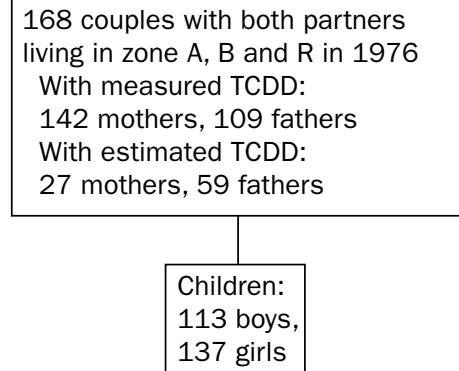

Characteristics of Seveso study population

The study includes couples with one or both partners living in A, B, and R contaminated zones in 1976 and their children born between April 1, 1977, and Dec 31, 1996.

\section{Methods}

\section{Population}

The Seveso population is an ideal study population for many reasons. ${ }^{17-24}$ TCDD, but not other PCDDs and PCDFs, and other chemicals substances such as sodium trichlorophenate, sodium hydroxide, and ethylene glycol, contaminated a wide area as a result of the 1976 explosion. Both men and women of various ages were exposed in different degrees. Serum samples from many of the exposed people have been stored since as early as July 1976, rendering it possible to measure the dioxin concentrations in blood soon after exposure.

The TCDD soil contamination levels in 1976 have been officially used to define the extent of environmental contamination. ${ }^{22}$ The contaminated zones were defined as the: A zone, by far the most polluted, housing about 750 people, all of whom were evacuated from the area within 2 weeks after the accident; B zone, less polluted, housing about 5000 people; and $\mathrm{R}$ zone, the least polluted, housing about 35000 people. We investigated the birth records of people who lived in the areas closest to the plant. These areas include all of the A zone, all of the $\mathrm{B}$ zone in Seveso, and a part of the $\mathrm{R}$ zone of Meda (so called Meda Polo). For the Seveso B and R zone areas, we investigated the family records for the history of births from April 1, 1977, to Dec 31, 1996, and for the A zone from Jan 1, 1966, to Dec 31, 1996. In addition we investigated the family records for the history of births for all people who lived in the B zone in Cesano Maderno and for whom we had a serum sample. We measured concentrations of dioxin in all available serum samples, which were taken from these parents in 1976 and 1977. These serum samples were samples that remained from laboratory tests that were offered at no cost to everyone in the exposed zones and surrounding areas in 1976 and 1977. More individuals living closer to the plant took advantage of these free laboratory tests than those who lived further away.

We located serum samples from mothers and fathers who were 3 to 45 years of age in 1976, who lived in these areas at the time of the explosion, and who produced offspring between April 1, 1977, and Dec 31, 1996.

We defined the "unexposed" as those people who lived outside the A, B, and R zones in July 1976 and those who lived inside these zones but who had a TCDD value equal to or less than 15 parts per trillion (ppt) on a serum lipid basis in $1976 .{ }^{21}$ Demographical information was officially obtained through the different municipalities' censuses and consisted of date of birth, town of residence in July 1976, date of marriage, date of children's birth, and sex of live births. All towns where study participants lived from 1971 to 1996 were recorded. Children born to unmarried people were also included in the study.

To compare the sex ratio in A zone before and after the accident, we checked demographical information between 1966 and 1996 on all people living in the A zone during the period from Jan 1, 1971, to July 10，1976. Information checked included the sex at birth and the same items as described above.

\section{Concentrations of TCDD in serum samples}

We measured by high-resolution-mass spectrometry ${ }^{25}$ the TCDD concentration in $0 \cdot 6-1 \cdot 0 \mathrm{~mL}$ serum samples that were collected and stored frozen since July 1976 in the University Laboratory of Desio-Milan Hospital. The results of 81 measurements designated as non-detectable were assigned a value of half the detection limit for that sample. To estimate an individual's year-by-year TCDD serum concentration between 1976 and 1996, we used Filser's model. ${ }^{26}$ We validated this model by measuring concentrations of serum dioxin in several exposed individuals in the Seveso area.

\section{Data analysis}

A general database was established and maintained using SAS software (version 6.12). A $\chi^{2}$ test with one degree of freedom was used to compare the observed sex ratios of offspring (males/[males+females]) in Seveso to the expected sex ratio of $0 \cdot 514 .{ }^{7}$ Univariate and multivariate logistic regressions were used to model the effects of the independent variables on the probability of a male birth. We used Generalised Estimating Equations (GEEs) to control for the correlation of observations among members of the same family.

Concentrations of TCDD in serum samples were included in the model as either dichotomous variable (parents who lived outside the $\mathrm{A}, \mathrm{B}$, and $\mathrm{R}$ zones and parents with TCDD concentrations less than or equal to $15 \mathrm{ppt}$ versus parents with serum concentrations greater than $15 \mathrm{ppt}$ ) or a three-level variable (parents with TCCD serum concentrations greater than $80 \mathrm{ppt}$, parents with TCDD concentrations greater than $15 \mathrm{ppt}$ and less than or equal to $80 \mathrm{ppt}$, parents living outside the $\mathrm{A}, \mathrm{B}$, and $\mathrm{R}$ zones, and parents with serum concentrations less than or equal to $15 \mathrm{ppt}$ ). These tertiles were created based on the distribution of TCDD among the parents. On the basis of previously published sex ratio, we also included the father's age and mother's age at their children's conception in our models (dichotomised at 35 years). A separate model was used to examine the link between the sex ratio and the father's age at exposure to TCDD.

\section{Missing data}

Among 168 couples with two exposed partners, 27 mothers and 59 fathers did not have concentrations of serum TCDD measured. TCDD values of married couples living in the same zone in 1976 were highly correlated. For 76 couples living in the same zone in 1976 (3, 27, 46 couples in A, B, and R zones respectively) we had a TCDD value for only one parent. In such cases, we substituted the serum dioxin concentration of the available parent for the missing value of the spouse. For ten couples not yet married in 1976, we had TCDD measurements for only one parent in each couple. All ten of these couples lived in the $\mathrm{R}$ zone. For the missing value, we substituted the median TCDD serum dioxin concentration for adults within the $\mathrm{R}$ zone (about $25 \mathrm{ppt}$ ). ${ }^{21}$ By substituting TCDD values for the missing 


\begin{tabular}{|c|c|c|c|c|c|}
\hline \multirow{2}{*}{$\begin{array}{l}\text { Father's } \\
\text { concentrations of } \\
\text { TCCD (ppt) }\end{array}$} & \multirow{2}{*}{$\begin{array}{l}\text { Mother's } \\
\text { concentrations of } \\
\text { TCDD (ppt) }\end{array}$} & \multicolumn{2}{|c|}{ Number of children } & \multirow{2}{*}{$\begin{array}{l}\text { Total } \\
\text { children }\end{array}$} & \multirow{2}{*}{$\begin{array}{l}\text { Sex } \\
\text { ratio } \\
(95 \% \mathrm{Cl})\end{array}$} \\
\hline & & Male & Female & & \\
\hline Unexposed* & Unexposed* & 31 & 20 & 51 & $\begin{array}{l}0.608 \\
(0.47-0.74)\end{array}$ \\
\hline$>15$ & $>15$ & 96 & 121 & 217 & $\begin{array}{l}0.442 \dagger \\
(0.38-0.51)\end{array}$ \\
\hline$>15$ & Unexposed* & 81 & 105 & 186 & $\begin{array}{l}0.436 \dagger \\
(0.36-0.51)\end{array}$ \\
\hline Unexposed* & $>15$ & 120 & 100 & 220 & $\begin{array}{l}0.545 \\
(0.48-0.61)\end{array}$ \\
\hline Total & & 328 & 346 & 674 & 0.487 \\
\hline
\end{tabular}

*People living outside A, B, and R zones on July 10, 1976, and people living in these zones with serum TCDD concentrations less than or equal to $15 \mathrm{ppt}$. + Different from expected sex-ratio value of 0.514 at $p=0.03$.

Table 1: Offspring sex ratio in the study population compared to the exposure status of parents

data, we were able to include all 674 children in our analyses. All statistical models contained a variable to identify substituted TCDD values versus actual TCDD values.

To find out how the imputation process affected our results, we repeated the models using only those exposed parents for whom we had actual TCDD measurements and the unexposed group consisting of the parents living outside the A, B, and R zones and those with TCDD values less than or equal to $15 \mathrm{ppt}$.

\section{Results}

We took 535 serum samples from 296 mothers and 239 fathers. The number of serum samples available from mothers who delivered a live birth and fathers who sired a live birth during the study period were: 86 (78\% of all mothers) from mothers and 88 (76\% of all fathers) from fathers in the A zone; 46 (37\%) from mothers and 47 (34\%) from fathers of Seveso B zone; 86 (24\%) from mothers and $59(17 \%)$ from fathers of Meda R (Meda Polo) zone; and 78 (estimated 19\%) from mothers and 45 (estimated $11 \%$ ) from fathers in the Cesano Maderno B zone. 154 women and 130 men had partners who lived outside the contaminated $\mathrm{A}, \mathrm{B}$, and $\mathrm{R}$ zones; the total number of families was 452 (figure).

The distribution of TCDD in parents' serum samples, calculated with measured TCDD concentrations were: fathers-median $96 \cdot 5 \mathrm{ppt}$ (range 2.8-26 $400 \mathrm{ppt}$ ), 25th and 75 th percentile 37.5 and 225 ppt; and mothersmedian $62 \cdot 75$ ppt $(6 \cdot 45-12500 \mathrm{ppt}), 25$ th and 75 th percentile $29 \cdot 25$ and 162.5 ppt. The overall recorded sex ratio of 0.487 was not significantly different from the expected sex ratio of 0.514 (table 1). However, when the 674 children were analysed according to parental exposure status, sex ratios different from the expected value of 0.514 ( $p$ value 0.03 ) were seen in the groups where either both parents or just the father had TCDD concentrations greater than $15 \mathrm{ppt}$ in 1976. If the mother was the only parent with a TCDD value greater than the 15 ppt baseline or if both parents had TCDD

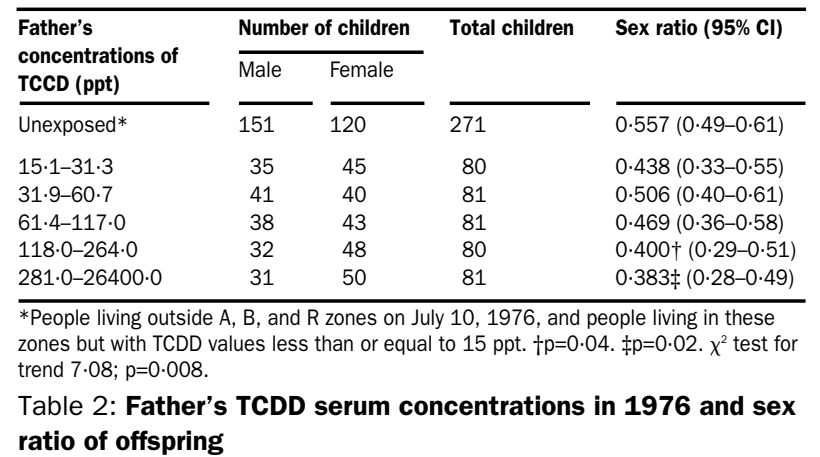

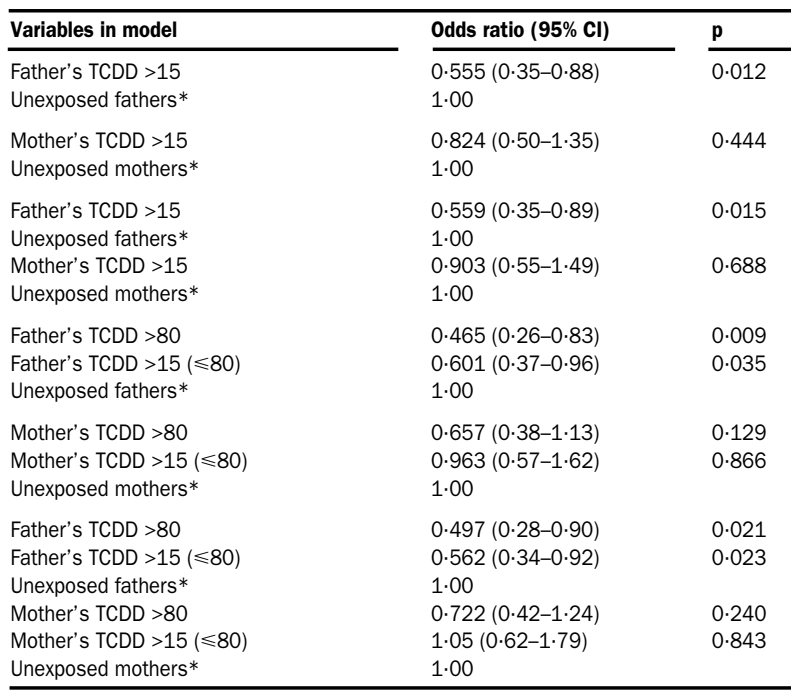

*People living outside A, B, and R zones on July 10, 1976, and people living in these zones with TCDD values less than or equal to $15 \mathrm{ppt}$.

Table 3: Odds of male births compared to the TCDD serum concentrations of his parents

concentrations less than or equal to $15 \mathrm{ppt}$, the sex ratio was not significantly different from 0.514 (table 1 ). To explore how parental TCDD exposure was related to the probability of a male birth, we analysed the data using univariate and multivariate models. Separate variables were created based on the father's and the mother's TCDD serum concentrations. The $\chi^{2}$ test for trend indicated that increasing serum TCDD concentrations in the father were associated with a decrease in the proportion of male births $\left(\chi^{2} 7 \cdot 08 ; p=0.008\right.$; table 2$)$. In the univariate model, the father's exposure was a significant predictor of a male birth. The probability of a male birth in the exposed group was significantly lower (odds ratio 0.555 [95\% CI $0.35-0.88]$ ) than in the unexposed group (table 3). When we repeated the analysis with only those exposed parents for whom we had actual TCDD measurements and the parents who lived outside the $\mathrm{A}, \mathrm{B}$, and $\mathrm{R}$ zones, our results and conclusions were similar. Neither the father's age nor the mother's age at conception (dichotomised at less than or equal to 35 years $v s>35$ years) was associated with a change in the expected sex ratio. The odds ratios were $1.00(0.70-1.43)$ for fathers and $1.10(0.66-1.83)$ for mothers. When both the father's and the mother's dichotomised exposure were included in a model, the father's exposure remained significant (odds ratio 0.559 [0.35-0.89]) (table 3). One of the variables of interest was the age of the father at the time of the explosion. We hypothesised that exposure to TCDD at younger ages would have a greater effect on the sex ratio than

\begin{tabular}{|c|c|c|c|}
\hline \multirow[t]{2}{*}{ Exposure status for TCDD } & \multicolumn{2}{|c|}{ Children } & \multirow[t]{2}{*}{ Sex ratio $(95 \% \mathrm{Cl})$} \\
\hline & Male & Female & \\
\hline Fathers unexposed* (all ages) & 151 & 120 & $0.557(0.50-0.62)$ \\
\hline $\begin{array}{l}\text { Fathers exposed }+ \text { (younger than } 19 \text { years } \\
\text { in 1976) }\end{array}$ & 50 & 81 & $0.382 \ddagger \S(0.30-0.47)$ \\
\hline $\begin{array}{l}\text { Fathers exposedt (older than } 19 \text { years } \\
\text { in 1976) }\end{array}$ & 127 & 144 & $0.469 \S(0.41-0.53)$ \\
\hline
\end{tabular}

*People living outside A, B, and R zones on July 10, 1976, and people TCDD values less than or equal to 15 ppt. †Exposure defined as TCDD $>15$ ppt on serum lipid basis, that was the baseline value in 1976 . $¥$ Sex ratio differs significantly from expected sex ratio of 0.514 at $p=0.002$. \$Probability that a male birth differed significantly from odds ratio of 0.514 at $p=0.002$. $\S$ Probability
ratio in unexposed group at $p<0.05$.

Table 4: Age and exposure status of father in 1976 and sex ratio of offspring 


\begin{tabular}{|c|c|c|c|c|c|c|}
\hline \multirow{2}{*}{$\begin{array}{l}\text { TCDD } \\
\text { concentra- } \\
\text { tion at } \\
\text { conception } \\
\text { (ppt) }\end{array}$} & \multirow{2}{*}{$\begin{array}{l}\text { Mean (SD) } \\
\text { age (years) } \\
\text { at exposure }\end{array}$} & \multicolumn{2}{|c|}{$\begin{array}{l}\text { Number of } \\
\text { children }\end{array}$} & \multirow[t]{2}{*}{ Sex ratio $(95 \% \mathrm{Cl})$} & \multirow{2}{*}{$\begin{array}{l}\text { Mean (SD) } \\
\text { fathers' age } \\
\text { (years) at } \\
\text { conception }\end{array}$} & \multirow{2}{*}{$\begin{array}{l}\text { Mean (SD) } \\
\text { mothers' age } \\
\text { (years) at } \\
\text { conception }\end{array}$} \\
\hline & & Male & Female & & & \\
\hline $3 \cdot 0-5 \cdot 6$ & $11.6(2.89)$ & 13 & 19 & $0.406(0.24-0.58)$ & $28.5(3.4)$ & $26 \cdot 7(4 \cdot 2)$ \\
\hline $5 \cdot 7-11 \cdot 5$ & $13 \cdot 4(3 \cdot 4)$ & 11 & 22 & $0.333(0.17-0.49)$ & $29.0(3.5)$ & $26.5(3.6)$ \\
\hline $11 \cdot 6-26 \cdot 9$ & $14 \cdot 8(2 \cdot 7)$ & 11 & 22 & $0.333(0.17-0.49)$ & $27 \cdot 3(3 \cdot 0)$ & $25.5(2.6)$ \\
\hline $27-1140$ & $15 \cdot 4(3 \cdot 1)$ & 15 & 18 & $0.455(0.29-0.62)$ & $28 \cdot 7(4 \cdot 3)$ & $25.5(4.0)$ \\
\hline \multicolumn{7}{|c|}{$\begin{array}{l}\text { *Exposure was calculated according to a previous study. }{ }^{25} \text { Includes } 92 \text { men younger } \\
\text { than } 19 \text { years of age in } 1976 \text { exposed to TCDD concentrations higher than } 15 \text { ppt. }\end{array}$} \\
\hline & & & & austile of fath & & \\
\hline
\end{tabular}

exposure at older ages. We tested this hypothesis by modelling the probability of a male birth among three groups: those who were not exposed in 1976; those less than 19 years of age; and those greater than or equal to 19 years of age when exposed in 1976. The sex ratios for children born to unexposed fathers were similar regardless of their age in 1976. For fathers younger than 19 years of age, the sex ratio was 0.535 [0.448-0.622] and for fathers at least 19 years of age, the sex ratio was $0.577[0.494-0 \cdot 660]$. Both exposed groups differed significantly when compared with the unexposed group (odds ratio [less than 19 years of age $v s$ unexposed] $0 \cdot 41$ [95\% CI $0 \cdot 23-0 \cdot 72$ ]; odds ratio [greater than or equal 19 years of age $v s$ unexposed] $0.61 \quad[95 \%$ CI $0 \cdot 38-0.97])$. However, only the sex ratio in the group exposed at less than 19 years of age differed significantly from the expected sex ratio of 0.514 (table 4).

The 92 men who had concentrations of serum dioxin greater than $15 \mathrm{ppt}$ and who were younger than 19 years of age in 1976 sired children from 1984 onwards; the median year for the birth of their offspring was 1991. We found that they fathered significantly more girls than boys, even in 1991, more than 15 years after the 1976 exposure. For these 92 fathers we estimated the concentrations of serum dioxin at the time of conception (table 5) by means of Filser's model ${ }^{26}$ of TCDD metabolic elimination. This method has been previously validated with real measurements from people exposed to TCDD in Seveso (unpublished data).

The distribution of the sex ratio at birth in the A zone before and after the accident is shown in table 6 . After a "normal" sex-ratio period (1966 to 1972), we found a substantially clear increase in the number of females born from 1973 through to 1976. This trend in the A zone continued in the period 1977 through to 1984 for those parents who had lived for some period of time in the A zone between 1971 and 1976. The parents' average age at conception of their child (table 6) are comparable across calendar years, ruling out this possible confounding factor. The sex ratio in the nearby town of Seregno (population of about 39000 ), which is located outside of the contaminated areas but which has

\begin{tabular}{|c|c|c|c|c|c|c|}
\hline Year & $\begin{array}{l}\text { Number } \\
\text { of males } \\
\text { (births } \\
\text { per year) }\end{array}$ & $\begin{array}{l}\text { Number } \\
\text { of females } \\
\text { (births } \\
\text { per year) }\end{array}$ & $\begin{array}{l}\text { Total } \\
\text { children }\end{array}$ & $\begin{array}{l}\text { Sex } \\
\text { ratio }\end{array}$ & $\begin{array}{l}\text { Mean (SD) } \\
\text { father's age } \\
\text { (years) at } \\
\text { conception }\end{array}$ & $\begin{array}{l}\text { Mean (SD) } \\
\text { mother's age } \\
\text { (years) at } \\
\text { conception }\end{array}$ \\
\hline $1966-72$ & $65(9 \cdot 3)$ & $59(8.4)$ & 124 & 0.524 & $31.5(5.5)$ & $27 \cdot 8(5 \cdot 8)$ \\
\hline 1973-76 & $29(7 \cdot 2)$ & $56(14 \cdot 0)$ & 85 & $0.341 *$ & $29 \cdot 3(4 \cdot 6)$ & $25 \cdot 8(4.9)$ \\
\hline $1977-84$ & $51(6 \cdot 4)$ & $72(9 \cdot 0)$ & 123 & $0.414 \dagger$ & $29.9(4 \cdot 7)$ & $26.5(4.9)$ \\
\hline $1985-90$ & $53(8 \cdot 8)$ & $43(7 \cdot 2)$ & 96 & 0.552 & $31.8(5 \cdot 6)$ & $28 \cdot 0(5 \cdot 0)$ \\
\hline $1991-96$ & $33(5 \cdot 5)$ & $37(6 \cdot 2)$ & 70 & 0.471 & $31 \cdot 8(4 \cdot 4)$ & $28 \cdot 1(4 \cdot 4)$ \\
\hline
\end{tabular}

Table 6: Sex ratio of births in residents of $\mathbf{A}$ zone from Jan 1, 1966, to Dec 31, 1996 similar types of industrial, environmental, and socioeconomic conditions was "normal" between 1966 and 1996 according to the census records. The question arises as to whether the change in sex ratio starting in 1973 in the A zone is due to TCDD contamination. Unfortunately we do not have serum samples from before 1976.

The possibility that a change in the sex ratio was caused by TCDD contamination seems plausible for two indirect reasons. A report by Zurlo ${ }^{27}$ states that 50 cycles of TCP production were produced at the ICMESA factory from summer 1971 to the middle of 1972 and from 1975 for a total of 180 cycles before July 10, 1976. We located five men who lived in the A zone from 1974 to early 1976, but who declared that they were not there on July 10, 1976, and that they had never returned to the area. We measured dioxin concentrations in serum samples obtained in 1976 and found TCDD concentrations ranging from 138-352 ppt. These results indicate high exposures in the A zone before July 10, 1976.

We also recorded that the total number of births by year to couples living in the A zone between 1966 and 1972 and between 1973 and 1976 was similar (table 6); however, there was an increase in the number of females born during the period between 1973 and 1976. This change in the expected sex ratio can be considered an indirect index of TCDD exposure of A-zone residents since 1972. These A-zone residents may have been exposed to dioxin as a result of emissions from a small incinerator that was built inside the factory to eliminate the chemical byproducts of trichlorophenol production. ${ }^{27}$

\section{Discussion}

Our data relate a modification in the expected human sex ratio in a residential population that was known to have been exposed to the environmental toxicant TCDD. We confirm our preliminary observation ${ }^{3}$ that high concentrations of dioxin in serum samples of parents in our study are linked to a lower sex ratio of their offspring. In addition, we have shown that serum dioxin concentrations lower than those already shown ${ }^{3}$ may have a similar effect if the father is exposed. Concentrations of TCDD of less than $80 \mathrm{ppt}$ in serum samples from fathers were a significant predictor of the probability of a male birth. TCDD concentrations in serum samples from mothers were not a significant predictor of the probability of a male birth.

Furthermore, male exposure to TCDD before and during puberty is linked to this sex-ratio effect, as seen by their offspring being predominantly female even though their offspring were conceived several years after the fathers' exposure when concentrations of dioxin in their serum samples were much lower. This indicates that the time before and during puberty may be a very sensitive period for dioxin toxicity in men. The predominance of females among their offspring raises the very important question of whether the lowered sex ratio is a result of a permanent effect from the moment of exposure, or if it is due to the presence of sufficient concentrations of dioxin in their bodies. Data in table 5 support the hypothesis of a permanent effect from the moment of exposure among men who were exposed before and during puberty. This effect is evident by the increase of female babies sired by these exposed men even though they had dioxin concentrations of less than $30 \mathrm{ppt}$, and even less than 15 ppt, at the time of conception of their offspring. These 
fathers, however, were exposed to dioxin several years earlier after an explosion, and thus they previously had serum concentrations greater than concentrations measured at the time they conceived a child.

Although this study does not provide evidence that serum dioxin concentrations of around $15 \mathrm{ppt}$ lead to a decreased sex ratio, the evidence of this effect starts at initial TCDD concentrations lower than 80 ppt (lower than 16 ng per kg body-weight).

Our data support a different action of TCDD in the two sexes, with females being insensitive to the effects of TCDD. The mechanism for regulation of the normal sex ratio of 0.514 is unknown. Most studies have not identified a deviation from $50 \%$ for each sex chromosome. ${ }^{28}$ Whether a high incidence of miscarriage of female fetuses is responsible for more male live births in the general population is not clear. ${ }^{29}$ Because of the lack of knowledge about the physiological mechanism, we can only hypothesise about the role of dioxin in lowering the sex ratio in human beings.

The link between the median 1976 body concentration of dioxin (about $20 \mathrm{ng}$ per $\mathrm{kg}$ bodyweight [range 3.5-3960] based on our serum measurements) in men before and during puberty, and the postpubertal effect on the sex ratio of offspring, is in agreement with experimental data that show a permanently altered sperm-transit time through the epididymus ${ }^{30,31}$ in adult rats exposed in utero or during lactation to mothers who were exposed to TCDD at concentrations of $64 \mathrm{ng}$ per kg bodyweight, ${ }^{30}$ and at $25 \mathrm{ng}$ per kg bodyweight. ${ }^{32}$

Bonduelle and colleagues ${ }^{33}$ found that the sex ratio of children born after intracytoplasmic sperm injection (ICSI) with testicular or epididymal spermatozoa was modified to 0.40 and 0.60 , for males and females, respectively. Additional data from Bonduelle (personal communication) show a significant difference $(p=0.05)$.

In-utero exposure is widely considered to be the most sensitive exposure time in terms of reproductive effects, but the time before and during puberty is also considered quite sensitive. ${ }^{30}$ These experimental data and our observation of the lower sex ratio among the offspring of men who were exposed to dioxin during adulthood or before and during puberty support the hypothesis that dioxin permanently affects the human epididymus from the time of exposure.

Also of interest is the finding ${ }^{34}$ that oestrogen receptor protein is present in human spermatozoa, which like the epididymus have $\mathrm{AH}$ receptors. In addition, antioestrogenic drugs, such as clomifene citrate and tamoxifen, ${ }^{35}$ were shown to enhance the functionality of spermatozoa induced by oestradiol. ${ }^{36}$ To gain more insight, it would be interesting to know the sex ratio of newborns sired by asthenoazoospermic men who had been treated with an antioestrogen such as tamoxifen. Dioxin has also been shown to have antiandrogenic properties, ${ }^{30}$ which could cause a change in the sex ratio. Animal models are needed to study these phenomena.

Our finding of an altered sex ratio in the Seveso population is in agreement with the increase in females sired by fathers exposed to chlorophenates, which are known to contain traces of various dioxin congeners. ${ }^{12,13}$ Unfortunately, the serum dioxin concentrations in the studies of these occupationally exposed fathers were not determined. In our study, the median body concentrations in men and women living in 1976 in the three exposed zones, A, B, and R, was about
20 times the average normal concentration of TCDD in men and women in industrialised countries. $^{37}$ The observed TCDD effects seen in our study started at concentrations of less than $20 \mathrm{ng}$ per $\mathrm{kg}$ bodyweight. This could have important public-health implications.

We thank Elisabetta Gonella and Raffaella Sala for technical assistance. This study was supported by Grant 2896 from Regione Lombardia, Milano, and from Fondazione Lombardia Ambiente, Milano, Italy. We were funded in part by a grant R01ES07171 from the National Institute of Environmental Health Sciences.

\section{References}

1 Safe S. Modulation of gene expression and endocrine response pathways by $2,3,7,8$-tetrachlorodibenzo- $p$-dioxin and related compounds. Pharmacol Therap 1995; 67: 247-81.

2 Grassman JA, Masten SA, Walker NJ, Lucier GW. Animal models of human response to dioxin. Envir Health Persp 1998; 106 (suppl 2): S761-75.

3 Mocarelli P, Brambilla P, Gerthoux PM, Patterson DG Jr, Needham LL. Change in sex ratio with exposure to dioxin. Lancet 1996; 348: 409.

4 Di Domenico A, Cerlesi S, Ratti S. A two-exponential model to describe the vanishing trend of 2,3,7,8-tetrachlorodibenzo- $p$-dioxin (TCDD) in the soil of Sevesco, Northern Italy. Chemosphere 1990; 20: $1559-66$.

5 Rogan WJ, Gladen BC, Guo Y-L, Hsu CC. Sex ratio after exposure to dioxin-like chemicals in Taiwan. Lancet 1999; 353: 206.

6 Davis DL, Gottlieb MB, Stampnitzky JR. Reduced ratio of male to female births in several industrial countries: a sentinel health indicator? $\mathcal{F} A M A$ 1998; 279: 1018-23.

7 James WH. Evidence that mammalian sex ratio at birth are partially controlled by parental hormone levels at the time of conception. f Theor Biol 1996; 180: 271-86.

8 Moller H. Change in male:female ratio among newborn infants in Denmark. Lancet 1998; 348: 828-29.

9 Van der Pal-de Bruin KM, Verloove-Vanhorick SP, Roeleveld N. Change in male-female ratio among newborn babies in Netherlands. Lancet 1997; 349: 62 .

10 Marcus M, Kiely J, Xu F, McGeehin M, Jackson R, Sinks T. Changing sex ratio in the United States, 1969-1995. Fertil Steril 1998; 70: 270-73.

11 Allan BB, Brant R, Seidel J, Jarrel JF. Declining sex ratio in Canada. Canad Med Ass F 1997; 156: 37-41.

12 Dimid-Ward H, Hertzman C, Teschke K, Hershler R, Marion SA, Ostry A. Reproductive effects of paternal exposure to chlorophenate wood preservatives in the sawmill industry. Scand $\mathcal{F}$ World Environ Health 1996; 22: 267-73.

13 James WH. The sex ratio of offspring sired by men exposed to wood preservatives contaminated by dioxin. Scand $\mathcal{f}$ Work Environ Health 1997; 23: 69 .

14 Williams F, Lawson AB, Lloyd OL. Low sex ratio of births in areas at risk from air pollution from incinerators as shown by geographical analysis and 3-dimensional mapping. Int $\mathcal{F}$ Epidemiol 1992; 21: 311-19.

15 Astolfi P, Zonta LA. Reduced male births in major italian cities. Hum Reprod 1999; 14: 3116-19.

16 Williams F, Ogston SA, Lloyd OL. Sex ratio of births, mortality, and air pollution: can measuring the sex ratios of births help to identify health hazards from air pollution in industrial environments? Occup Environ Med 1995; 52: 164-65.

17 Mocarelli P, Marocchi A, Brambilla P, Gerthoux PM, Young DS, Mantel N. Clinical laboratory manifestations of exposure to dioxin in children: a six-year study of the effects of an environmental disaster near Seveso, Italy. $7 A M A$ 1986; 256: 2687-95.

18 Mocarelli P, Marocchi A, Brambilla P, et al. Effects of dioxin exposure in humans at Seveso, Italy. In: Gallo MA, Scheuplein RJ, van Der Heijden KA, eds. Banbury report 35: biological basis for risk assessment of dioxins and related compounds. Cold Spring Harbor: Cold Spring Harbor Laboratory Press, 1991: 95-110.

19 Mocarelli P, Needham LL, Marocchi A, et al. Serum concentration of 2,3,7,8-tetrachlorodibenzo-p-dioxin and test results from selected residents of Seveso, Italy. F Toxicol Environ Health 1991; 32: 357-66.

20 Mocarelli P, Marocchi A, Brambilla P, et al. Human data derived from the Seveso accident-relevance for human risk assessment. Toxic Subst f 1992; 12: 151-73.

21 Needham LL, Gerthoux PM, Patterson DG Jr, et al. Serum dioxin levels in Seveso, Italy, population in 1976. Teratogenesis Carcinog Mutagen 1997; 17: 225-70. 
22 Bertazzi PA, Bernucci I, Brambilla G, Consonni D, Pesatori AC. The Seveso studies on early and long-term effects of dioxin exposure: a review. Environ Health Perspect 1998; 106: 625-33.

23 Landi MT, Consonni D, Patterson DG Jr, et al. 2,3,7,8-TCDD plasma levels in Seveso 20 years after the accident. Environ Health Perspect 1998; 106: 273-77.

24 Needham LL, Gerthoux PM, Patterson DG Jr, et al. Exposure assessment: serum levels of TCDD in Seveso, Italy. Environ Res 1999; 80 (section A): S200-06.

25 Patterson DG Jr, Hampton L, Lapeza CR Jr, et al. High-resolution gas-chromatography/high-resolution mass spectrometric analysis of human serum on a whole weight and lipid basis for 2,3,7,8tetrachlorodibenzo-p-dioxin. Anal Chem 1987; 59: 2000-05.

26 Kreuzer PE, Csanady GyA, Baur C, et al. 2,3,7,8tetrachlorodibenzo- $p$-dioxin (TCDD) and congeners in infants: a toxicokinetic model of human lifetime body burden by TCDD with special emphasis on its uptake by nutrition. Arch Toxicol 1997; 71: 383-400

27 Zurlo N. Incidente Icmesa ed interventi di bonifica. In: Disastro Icmesa. Scienza, pubblica amministrazione e popolazione di fronte alla tragedia tecnologica. Milano: Franco Angeli Press 1979; 209-22.

28 Lobel SM, Pomponio RJ, Mutter GL. The sex ratio of normal and manipulated human sperm quantitated by the polymerase chain reaction. Fertil Steril 1993; 59: 387-92.

29 Bartels I, Hansmann I, Eiben B. Excess of females in chromosomally normal spontaneous abortuses. Am f Med Genet 1990; 35: 297-98.

30 Roman E, Peterson RE. Developmental male reproductive toxicology of 2,3,7,8-tetrachlorodibenzo-p-dioxin (TCDD) and
PCBs. In: Korach KS, ed. Reproductive and developmental toxicology. New York: Marcel Dekker, 1998: 593-624.

31 Gray LE, Ostby S, Kelce WR. A dose-response analysis of the reproductive effects of a single gestational dose of 2,3,7,8tetrachlorodibenzo-p-dioxin in male Long Evans hooded rat offspring. Tox Appl Pharm 1997; 146: 11-20.

32 Faqi AS, Dalsenter PR, Merker HJ, Chahoud I. Reproductive toxicity and tissue concentrations of low doses of 2,3,7,8tetrachlorodibenzo-p-dioxin in male rats exposed throughout pregnancy and lactation. Tox Appl Pharm 1998; 150: 383-92.

33 Bonduelle $\mathrm{M}$, Wilikens A, Buysse A, et al. A follow-up study of children born after intracytoplasmic sperm injection (ICSI) with epididymal and testicular spermatozoa and after replacement of cryopreserved embryos obtained after ICSI. Hum Repr 1998; 13: 196-207.

34 Durkee TJ, Mueller M, Zinamam M. Identification of estrogen protein and messenger ribonucleic acid in human spermatozoa. $\mathrm{Am}$ f Obstet Gynecol 1998; 178: 1288-97.

35 Idaomar M, Guerin JF, Lornage J, Monchamont P, Czyba JC. Effects of estradiol and its antagonist-tamoxifen-on motility and metabolism of human spermatozoa. Adv Contracept 1987; 3: $337-41$.

36 Idaomar M, Guerin JF, Lorange J, Czyba JC. Stimulation of motility and energy metabolism of spermatozoa from asthenozospermic patients by 17B-estradiol. Arch Androl 1989; 22: 197-202.

37 DeVito MJ, Birnbaum LS, Farland WH, Gaswieicz TA. Comparisons of estimated human body burdens of dioxinlike chemicals and TCDD body burdens in experimentally exposed animals. Environ Health Perspect 1995; 103: 820-31. 